\title{
Diversity of large woody lignophytes preceding the extinction of Archaeopteris: new data from the middle Tournaisian of Thuringia (Germany)
}

Anne-Laure Decombeix *, Brigitte Meyer-Berthaud, Nick Rowe, Jean Galtier.

Botanique et bioinformatique de l'architecture des plantes (UMR 5120 CNRS-CIRAD), TA40/PS2, CIRAD, Boulevard de la Lironde, 34398 Montpellier cedex 5, France

\section{Abstract}

Anatomically preserved axes representing three lignophyte species occur in the middle Tournaisian deposit of Kahlleite in Thuringia. One is characterized by a small oval eustele, short uniseriate rays, and alternate distichous phyllotaxy. It is assigned to the progymnosperm genus Protopitys. The two others share a eustelic primary vascular system comprising a parenchymatous pith and numerous xylem strands in a peripheral position. The secondary xylem comprises rays that are mostly uniseriate and rarely exceed 20 cells in height. One is referred to as Eristophyton sp.; the second, characterized by ray cells showing a wide range of sizes and shapes is assigned to Aporoxylon primigenium. These records extend the stratigraphical range of Protopitys and Eristophyton down to the middle Tournaisian and confirm their great longevity through most of the Mississippian. They suggest that the diversity of putative arborescent lignophytes co-occurring with Archaeopteris around the D/C boundary but surviving successfully above this limit has been underestimated.

\section{Introduction}

The lignophytes, a monophyletic group of plants characterized by the possession of a bifacial vascular cambium, comprise the Palaeozoic progymnosperms and the spermatophytes

\footnotetext{
${ }^{*}$ Corresponding author. E-mail address : anne-laure.decombeix@cirad.fr
} 
(Crane, 1985; Doyle and Donoghue, 1986). Earliest remains of arborescent lignophytes, recognized as such from their large stem diameter and coniferous type of wood (= secondary xylem), are included in the Archaeopteridales, a progymnosperm order reported from the late Middle Devonian to the earliest Carboniferous deposits (Beck, 1962; Beck and Wight, 1988;

5 Fairon-Demaret, 1986; Hammond, 2004; Hoskins and Cross, 1951, 1952; Matten, 1972). Trees included in the genus Archaeopteris became the dominant components of Late Devonian forests, an assessment based on the abundance and worldwide distribution of their remains (DiMichele and Hook, 1992).

A substantial number of studies have been conducted in the last 30 years on taxa possessing pycnoxylic wood from Mississippian localities of western Europe spanning the late Tournaisian to late Visean (Galtier and Meyer-Berthaud, submitted). They represent the best source of information now available on Lower Carboniferous woody axes with a dense wood resembling that of Archaeopteris and presumed to belong to arborescent lignophytes. These axes show a broad range of vascular and cortical characters, which is the basis for assessing their taxonomic diversity. When and how these arborescent lignophytes evolve and how is this diversity related to the extinction of Archaeopteris slightly above the Devonian/Carboniferous boundary remains obscure.

The oldest known deposits of Carboniferous age yielding anatomically preserved plants are marine. They include the upper part of the New Albany Shale and equivalent levels of Illinois, Indiana, Kentucky and Tennessee (Hoskins and Cross, 1952), the Lydiennes of Montagne Noire (southern France) and the Rußchiefer of the Saalfeld area in Thuringia (Scott et al., 1984). Apart from Archaeopteris (Beck, 1962; Matten, 1972), few specimens with dense wood were recovered from such deposits and none have been reinvestigated since their early descriptions in the late 1800's and early 1900's. Archaeopitys eastmanii is the single species of this type reported from the New Albany Shale of Kentucky (Scott and Jeffrey, 1914). None have yet been formerly described from the Montagne Noire. In the Saalfeld area, two fragments of axes possessing pycnoxylic wood were referred to as Aporoxylon primigenium, a name emphasizing the supposedly non-pitted walls of the tracheids (Unger, 1856). Medullary rays in the secondary xylem were relatively high (up to 20 cells) and often biseriate. A second species, Araucarites ungeri, was later described based on better preserved specimens showing pitted tracheid walls but smaller rays than Aporoxylon (Goeppert and Stenzel, 1888). Conspecificity between the two taxa was suggested but remains uncertain (Goeppert and Stenzel, 1888). Recent attempts to find the historical locality of Mount Pfaffenberg that yielded most of the flora described by Unger (1856) were unsuccessful. 
However investigation of Rußchiefer beds cropping out in a quarry at Kahlleite about $25 \mathrm{~km}$ east of Saalfeld resulted in the discovery of a new assemblage of anatomically preserved plants (Meyer-Berthaud and Rowe, 1996). The objectives of this paper are the following. First is to provide a detailed description of the three axes of the assemblage possessing dense wood and preserved stele and to assess their affinities. Second is to discuss their significance concerning the diversity of arborescent lignophytes soon after the $\mathrm{D} / \mathrm{C}$ boundary and in relation to the extinction of Archaeopteris.

\section{Materials and methods}

The three stems described in this paper (KLA17, KLC11, KLC25) were collected in the Kahlleite quarry, $1 \mathrm{~km}$ south-west of the village of Rödersdorf and a few hundred meters from the Buschteich quarry, on the eastern side of the Ziegenrück syncline (Weyer, 1990; Fig. 1). Plants occur in a marine formation, the Rußchiefer, which consists of alternating grey shales containing nodules and red to dark brown silicified beds. The Rußchiefer overlies a cephalopod limestone of early Tournaisian age (Tn1b), the Gattendorfia Kalk. It is overlain by turbiditic limestones containing calcareous foraminifers and algae from the photic zone indicating a Lower Visean age (Arundien; V1b-V2a). Plants that are concentrated in the basal beds of the Rußchiefer are late Hastarian (Middle Tournaisian; Weyer, 1990 and pers.com.; Fig. 1).

The stem fragments are anatomically preserved in a siliceous matrix. They show a relatively large ring of dense wood. All have lost their external tissues (outermost layers of wood and bark) but possess elements of the primary body (stele, traces to leaves/branches) that are important for taxonomic identification.

Anatomical study was carried out on ground thin-sections, wafers and peel-sections made in the transverse, radial, and tangential planes. Observations, drawings and photographs were made with an Olympus SZX9 stereomicroscope equipped with a camera lucida, and with an Olympus BX60 microscope. Measurements of cells and tissues were carried out using SigmaScan 3.02 software. When possible, a minimum of 100 measurements was taken for each parameter. When the number of measurements was less than 50, only the size range (minimum and maximum) is given. 
The material is currently deposited in the collections at laboratoire AMAP (Botanique et bioinformatique de l'architecture des plantes, Montpellier).

\section{Description}

\subsection{KLC 11-Protopitys sp. (Plate I)}

The specimen is more than $21 \mathrm{~cm}$ long and up to $2.4 \mathrm{~cm}$ in diameter in the bestpreserved parts. In cross section, the centre consists of a relatively small $(1.9 \times 1.7 \mathrm{~mm})$ oval eustele traversed by cracks that interrupt the cellular structure (Fig. 2A; Plate I, 1). The stele is surrounded by secondary xylem showing conspicuous signs of preservational compression in the distalmost centimetres of the specimen. Maximum wood thickness is $12 \mathrm{~mm}$. An incomplete growth ring can be traced around $1 / 3$ to $1 / 2$ of the circumference (Plate I, 2). Vascular traces were analysed in the proximal half of the specimen but preservation was insufficient for a detailed assessment of their emission patterns.

\subsubsection{Stele}

The elliptical pith is parenchymatous and comprises thin-walled cells ranging 30-130 $\mu \mathrm{m}$ (average: $62 \mu \mathrm{m}$ ) in diameter. In longitudinal section, pith cells are rectangular and higher than broad (average height: $85 \mu \mathrm{m}$ ) (Plate I, 3). The primary xylem is mainly distributed in two opposite zones occurring at each end of the ellipse and measuring up to $800 \mu \mathrm{m}$ tangentially (Plate I, 4). Each zone contains a reduced number of xylem strands, two generally visible in the best preserved portions. Protoxylem is difficult to locate and is either mesarch or endarch (Plate I, 7-8). Additional groups of metaxylem tracheids occur around the pith, against the secondary xylem, but do not form a continuous layer (Plate I, 5). Metaxylem tracheids are 17-98 $\mu \mathrm{m}$ (average: $36 \mu \mathrm{m}$ ) in diameter. Most display scalariform thickenings; some are reticulate (Plate I, 11).

\subsubsection{Secondary xylem}

Secondary xylem tracheids are polygonal to rectangular in transverse section and a little smaller than metaxylem tracheids. At $0.5 \mathrm{~mm}$ from the stele, their average diameter is 24 $\mu \mathrm{m}$ radially and $25 \mu \mathrm{m}$ tangentially (maximum $47 \mu \mathrm{m}$ ). They show no significant increase in size towards the periphery. In longitudinal section, groups of tracheids show curved end walls 
in contact with ray cells; some tracheids show long, narrow tapered end walls suggestive of apical intrusive growth. In most tracheids, bordered pits on the radial walls are uniseriate and circular, sometimes transversely elongated (Plate I, 12-13). Such pits are spaced and narrow, occupying about one-third of the tracheid diameter. Some tracheids also display crowded biseriate pits arranged in alternating rows (Plate I, 12). Apertures are oval to slit-like and oblique.

Rays are entirely parenchymatous. In transverse section, they are short and most do not exceed $0.5 \mathrm{~mm}$ in length (Plate I, 2). In tangential section they are small and their density is low $\left(20\right.$ rays $/ \mathrm{mm}^{2}$ ) (Plate I, 10). They are mostly uniseriate and $1-5$ cells high. $83 \%$ are only

101 cell high (Fig. 3) Individual ray cells are relatively high and narrow [24-114 $\mu \mathrm{m}$ in height (average: $59 \mu \mathrm{m}$ ) and 7-35 $\mu \mathrm{m}$ tangentially (average: $19 \mu \mathrm{m}$ )]. In radial section, their horizontal walls are often jagged. Groups of large, irregularly shaped, parenchymatous cells may connect successive rays. Rays with enlarged cells are more common in the inner part of the wood. Cross-fields comprise 4 to 8 closely appressed oval pits (Plate I, 13).

In transverse section, the growth ring boundary extends into one half of the stem, at 3-4 mm from the stele. It is characterised by 1-3 rows of cells that have appreciably lower radial diameters (average: $13 \mu \mathrm{m}$ ) than elsewhere in the wood (Plate I, 2). The ring boundary is sometimes double.

\subsubsection{Vascular traces}

Six successive vascular traces to lateral appendages are preserved in the lower half of the specimen. Traces depart from each of the two main zones of primary xylem in the stele, emerging from between a pair of broadly triangular xylem strands (Plate I, 7). In transverse section, the best preserved trace consists of a single, crescent-shaped strand of primary xylem measuring $300 \mu \mathrm{m}$ radially and $500 \mu \mathrm{m}$ tangentially at $3 \mathrm{~mm}$ from the stele (Plate I, 6). A large band of parenchyma connects it to the stele on the adaxial side. The abaxial side is bordered by a narrow gap. All other traces consist of two strands of primary xylem. Because of the amount of cracks in these areas, the double structure may be artefactual. Maturation, whether mesarch or endarch, of xylem traces is not clear. Traces are emitted alternately in two opposite rows (distichous alternate arrangement), with an average internode length of $2 \mathrm{~cm}$ (Fig.4). Their course ends within the secondary xylem, at 3-4 mm from the stele border and within the inner growth zone. This suggests that traces were mechanically broken relatively early during axis growth and that the appendages they innerved were deciduous.

In the distal, highly deformed, part of the specimen a $1 \mathrm{~mm}$ broad branch trace is 
included in the wood (Plate I, 9). The lighter part in the centre presumably corresponds to the thin-walled cells of a pith. It is unknown how this trace connects to the vascular system of the stem.

\subsection{KLA17-Eristophyton sp. (Plate II, 1-8)}

The specimen is $22.5 \mathrm{~cm}$ long and up to $4.5 \mathrm{~cm}$ in diameter. It comprises a broad (1.2 $\mathrm{cm}$ wide) parenchymatous eustele that has been moderately compressed and with a central part replaced by sediment (P1.II, 1). The surrounding preserved portion of wood is $1-2.2 \mathrm{~cm}$ thick and devoid of growth rings (Fig. 2B). The specimen is heavily mineralised, with zones of large crystals, and some anatomical characters (i.e. ray cells) are hardly distinguishable.

\subsubsection{Stele}

In the most complete transverse sections, 20-25 small discrete strands of primary xylem occur at the periphery of the broad pith (Fig. 2B; Plate II, 2). A total of 30 strands is estimated for the complete stele. All strands lie directly in contact with the secondary xylem. Their size varies from 80 to $230 \mu \mathrm{m}$ tangentially, the smallest ones protruding prominently within the pith (Plate II, 3). Protoxylem maturation is mesarch (Plate II, 3), possibly endarch in a few strands. Metaxylem tracheids range from 15 to $35 \mu \mathrm{m}$ in diameter and the largest show multiseriate bordered pits (P1 II, 6).

The pith is homogeneous consisting of large, round to polygonal, parenchymatous cells $72-180 \mu \mathrm{m}$ (average: $117 \mu \mathrm{m}$ ) in diameter. In longitudinal section, they appear broader than high (Plate II, 4) with a height of only 17-56 $\mu \mathrm{m}$ (average: $37 \mu \mathrm{m}$ ). Parenchyma cells at the pith periphery are smaller in transverse section. They are radially stretched when close to the primary xylem strands and sometimes difficult to distinguish from the metaxylem tracheids. In radial section, these peripheral pith cells are 1 to 3 times higher than broad.

\subsubsection{Secondary xylem}

In transverse section, secondary xylem tracheids are rectangular to polygonal (Pl. II, 2). Their size is equal to that of the metaxylem tracheids, with average radial and tangential diameters of $29 \mu \mathrm{m}$ and $30 \mu \mathrm{m}$ respectively (maximum diameter: $56 \mu \mathrm{m}$ ). These dimensions do not change significantly across the wood diameter. Ornamentation of the tracheid walls in 
radial section consists of 2-3, sometimes 4, rows of contiguous bordered pits with oval apertures (Plate II, 7).

In transverse section, rays alternate with 2-16 rows of tracheids. Some are long and cross the entire wood width. They do not widen significantly close to the pith. In tangential section, ray outlines can be assessed with some confidence but the number and size of cells is uncertain. Best preserved rays are uniseriate, seldom partly biseriate (about 5\%) with a maximum height of 15 to 20 cells (Plate II, 5). Ray cells are square to rectangular in shape, 20-35 $\mu \mathrm{m}$ broad and 10-45 $\mu \mathrm{m}$ high. In radial section ray cells are longer than high. Crossfield pitting is unknown.

\subsubsection{Leaf traces}

Leaf traces are circular, small (approximately $200 \mu \mathrm{m}$ in transverse section), with a single mesarch strand of protoxylem (Plate II, 8). They diverge tangentially from cauline primary xylem strands and cross the innermost part of the wood at a very acute angle, without any division or change in diameter. The most distant trace from the stele occurs at a distance of only $4 \mathrm{~mm}$ within the wood indicating that leaf traces were mechanically broken during axis growth, and leaves probably deciduous. Arrangement of the departing traces in crosssection indicates a spiral phyllotaxy. Up to 4 traces per transverse section are visible in the wood. Due to their steep course, several seem sectioned at the same level but careful observation shows that they enter into the wood successively.

\subsection{KLC 25-Aporoxylon primigenium (Plate II, 9-15)}

The specimen is segmented in 7 pieces not interconnected. The most informative one is $7 \mathrm{~cm}$ long, up to $5 \mathrm{~cm}$ in diameter, and comprises a small eustele (10 x $2 \mathrm{~mm}$ wide) (Plate II, 9). The surrounding preserved portion of wood is 1-2 $\mathrm{cm}$ thick and devoid of growth rings (Fig. 2C). Both stele and secondary xylem show evidence of compression. The remaining fragments consist of wood with occasional remains of pith cells attached.

\subsubsection{Stele}

The primary xylem is comprised of at least 18 primary xylem strands either separated or tangentially connected to each other at the periphery of the pith. In transverse section, individual strands measure 100 to $250 \mu \mathrm{m}$ wide tangentially (Plate II, 10). All are in contact 
with the secondary xylem and have a mesarch maturation. Metaxylem tracheids measure 10$55 \mu \mathrm{m}$ in diameter.

Pith cells are all parenchymatous but their diameter is highly variable in transverse section, ranging from 22 to $145 \mu \mathrm{m}$ (Plate II, 11). In longitudinal section, these cells are square to rectangular, the narrowest being usually much higher than wide.

\subsubsection{Secondary xylem}

In transverse section, secondary xylem tracheids are mostly rectangular (Plate II, 12). Their size is similar to that of the metaxylem tracheids, with radial and tangential diameters about $25 \mu \mathrm{m}$ (maximum: $49 \mu \mathrm{m}$ ). There is no significant increase in size towards the periphery. Radial walls of tracheids show 2-3 rows of bordered pits. Rays are separated by 211 rows of tracheids. Some are a little wider close to the pith. In tangential section, most rays are 1-2 cells wide (Plate II, 13-14), some are partially triseriate. Their maximum height observed is 28 cells but the majority (79\%) are 1-10 cells high (Fig. 5). Ray cells show a wide range of shapes and sizes, tending to be large and rectangular in uniseriate portions of rays (Plate II, 13), small and square to polygonal in multiseriate zones (Plate II, 14). They measure 17 to $60 \mu \mathrm{m}$ (average: $30 \mu \mathrm{m}$ ) in height and 12 to $43 \mu \mathrm{m}$ (average: $25 \mu \mathrm{m}$ ) in width. In radial section ray cell outlines are hardly distinctive and the cross-field pitting and shape of ray cells are unknown.

\subsubsection{Leaf traces}

Leaf traces are circular in transverse section and measure about $200 \times 300 \mu \mathrm{m}$ throughout their course (Plate II, 15). They have a mesarch pole of protoxylem and may show parenchyma on the adaxial side when they are close to the stele. Their course makes an angle of $50-60^{\circ}$ with the vertical axis of the stele and stops within the wood. The most distant trace observed is $1.8 \mathrm{~cm}$ from the stele border, close to the outer limit of the specimen.

\section{Affinities}

30

\subsection{KLC 11}

Primary vascular organization and wood structure indicate affinities with the Mississippian species Protopitys buchiana Goeppert, Protopitys scotica Walton and 
Endoxylon zonatum Scott. The first two are included in the Protopityales (Progymnosperms). The third is only known from two fragments of axis described by Scott (1924) and Lacey (1953) respectively. E. zonatum is currently included in the pteridosperms but its affinities are dubious and its wood structure shows numerous similarities with the genus Protopitys (Galtier, 1992). Traits shared by these three species and the Kahlleite specimen include: (1) a eustele comprising a small number of primary xylem strands (less than 10) at the periphery of a parenchymatous pith; (2) endarch to mesarch maturation of the primary xylem; (3) very low rays, which are mostly uniseriate. Traits shared more specifically with Protopitys include (1) an oval stele comprising two main zones of primary xylem at opposite ends and arc-shaped vascular traces. This is more similar to Protopitys than to Endoxylon, which shows 7-8 strands of primary xylem evenly distributed around a circular pith, and circular traces to lateral appendages (Lacey, 1953; Scott, 1924) (Table 1). (2) Emission of traces, which is consistent with the distichous alternate phyllotaxy found in both Protopitys species. (3) Internode length, which is of the same range as in P. scotica. (4) There is also resemblance with P. buchiana in the compact arc-shaped traces but KLC 11 differs from that species by the discontinuity of the metaxylem layer bordering the pith and the lack of scalariform pits on the radial walls of the wood tracheids (Galtier et al., 1998; Goeppert, 1850; Scott, 1923). (5) Radial ornamentation of these tracheids is mostly uniseriate in the Kahlleite specimen and resembles more that of the innermost elements of the wood of P. scotica. But uniseriate bordered pits in the latter species are wider transversely and closer to each other, occupying most of the tracheid diameter (Smith, 1962; Walton, 1957) and multiseriate pitting characterizing most of the secondary xylem in P. scotica is only occasional in specimen KLC 11. Other differences between the secondary xylem of the Kahlleite specimen and that of the two formerly described species of Protopitys are quantitative. Tracheids are smaller, ray cells larger and ray density lower in specimen KLC 11. Because of such differences, this specimen is referred to as Protopitys sp.

\subsection{KLA 17 and KLC 25}

Specimens KLA 17 and KLC 25 share a eustelic primary vascular system comprising numerous xylem strands in a peripheral position and a significant amount of secondary xylem. Their pith is entirely parenchymatous and lacks the intramedullary xylem strands that characterize the genera Pitus (Gordon, 1935; Scott, 1902) and Archaeopitys (Scott and 
Jeffrey, 1914), the sclerotic nests of Cauloxylon (Cribbs, 1939), and the pitted cells of Bilignea (Galtier et al., 1993; Galtier and Scott, 1994; Scott, 1924). Besides, rays in the secondary xylem of the Kahlleite specimens appear smaller in tangential section than those recorded in Pitus and Cauloxylon. The genera presenting most similarities with KLA17 and KLC 25 are Eristophyton (Zalessky) Lacey and Aporoxylon Unger.

Regarding Eristophyton, specimens KLA17 and KLC 25 are consistent with the wide concept proposed by Lacey (1953) on the basis of the following characters (1) lack of medullary xylem strands or tracheids, (2) numerous endarch to mesarch primary xylem strands that may be in contact with the wood, (3) numerous small leaf traces undivided proximally, produced spirally, and separated by short internodes, (4) dense wood comprising small to medium-sized parenchymatous rays and narrow tracheids with multiseriate bordered pitting.

Eristophyton includes 3 species and the Kahlleite specimens differ from all three (Table 2) (Galtier et al., 1993; Galtier and Scott, 1990; Galtier and Scott, 1994; Lacey, 1953; Long, 1987; Scott, 1902). Similarities with E. fasciculare Scott include an entirely parenchymatous pith, mainly mesarch primary xylem strands, and ray size. Similarities with E. waltonii include small primary xylem strands and small leaf traces. But in contrast with these two species, the proximal portion of their primary xylem strands is never detached from the wood. Another difference with E. fasciculare is the smaller size of the leaf traces in the Kahlleite specimens; with E. waltonii, it is the smaller size of the rays in the Kahlleite specimens. Conspicuous sclerotic nests occur in the pith of both E. waltonii and $E$. beinertianum. They are absent in KLA 17 and KLC 25, which rules out a close affinity with E. beinertianum, though the location of primary xylem strands and ray size are similar.

The genus Aporoxylon comprises one species, A. primigenium, represented by several decorticated axes from the Tournaisian of the Saalfeld area. Hörich (1915) showed that the unpitted aspect of the tracheid walls stressed by Unger (1856) in his diagnosis was artefactual (Plate III, 2). In a new specimen claimed to be anatomically similar to Unger's original material, a faint pattern suggestive of several rows of densely packed bordered pits was present on the radial walls of the secondary xylem tracheids. Interestingly, Hörich noted that this new specimen was found in a locality on the north-eastern side of the Grossen Buschteich quarry. This location fits with that of the Kahlleite quarry. Based on the few published works presenting illustrations of $A$. primigenium and our own observation of slides from the original material currently housed in the Museum d'Histoire Naturelle de Paris (specimen 19, slides 430, 432, 433), the characters shared by KLA 17, KLC 25 and Aporoxylon include (1) a large 
parenchymatous pith devoid of medullary tracheids and sclerotic nests, (2) primary xylem consisting of numerous small strands, (3) comparable size of leaf traces, (4) dense wood (plate II, 12; plate III, 1) with narrow tracheids and parenchymatous rays about 20 cells high (plate II, 5, 13, 14; plate III, 3-6; fig. 5). Rays in Aporoxylon primigenium, however, are distinctive. Like those in KLC 25, they consist of parenchymatous cells showing a wide range of sizes and shapes indicative of multiple patterns of divisions in the ray initials (plate II, 14; plate III, 3-6).

In the present state of knowledge, Aporoxylon and Eristophyton are two broadly defined genera that show some overlap. KLC 25 which shows the heterogenous type of rays of Aporoxylon primigenium is assigned to this taxon. Based on ray structure, KLA 17 is assignable to Eristophyton but differs from the three species already described in the genus. It is referred to as Eristophyton $s p$.

\section{Discussion}

15

There is no direct evidence that the taxa described in this paper and based on decorticated specimens were arborescent, i.e. that they were self-supporting and showed the growth potentials resulting in organisms that are high and possess broad axes. However, from the four types of mechanical growth forms recently identified among early lignophytes (Rowe et al., 1993; Speck and Rowe, 1994, 2003), the Kahlleite specimens resemble a selfsupporting organisation possibly like that observed in Pitus dayi. Although the primary cortical features of the Kahlleite specimens are unknown, features of the wood cylinders differ from those of the probably semi-self-supporting Calamopitys and Lyginopteris. They include relatively thick-walled, small diameter tracheids, and relatively dense wood with narrow rays, which probably conferred stiff mechanical properties during later stages of ontogeny when the wood cylinder was the main contributing tissue to the stem. In addition, two of the Kahlleite axes are assigned to the genera Protopitys and Eristophyton that include bona fide arborescent species. The Visean species $P$. buchiana includes stems exceeding 40 $\mathrm{cm}$ in diameter (Solms-Laubach 1893, Beck \& Wight, 1988), and a $24 \mathrm{~cm}$ wide decorticated portion of trunk of Eristophyton waltonii was reported in the late Tournaisian deposits of Castleton Bay (Galtier \& Scott, 1990). These data suggest that the Kahlleite specimens share certain features of development with other species of genera known to produce large-bodied and arborescent, probably self-supporting trees. 
The three specimens from Kahlleite are not well preserved but show features demonstrating a not insignificant diversity of lignophyte organisation present in this middle Tournaisian locality. KLC 11 displays the distinctive oval stele, distichous phyllotaxis and very small rays of Protopitys axes. KLA 17 (Eristophyton sp.) has a wide circular pith, small discrete strands of primary xylem that are widely separated from each other, and a majority of uniseriate rays consisting of cells that are uniform in size and shape. In KL C25 (Aporoxylon primigenium), the pith is heterogeneous in terms of cell size, and primary xylem strands may be confluent; the secondary xylem shows more and larger rays than in the two other specimens and these rays comprise cells of variable sizes and shapes; the course of leaf traces across the wood is longer and more inclined than in KLA 17.

KLA 17 and KLC 25 share a number a features that deserve some comments from an evolutionary point of view. The araucarian type of pitting of the tracheid walls and the relatively small rays that characterize the secondary xylem are two plesiomorphic traits shared with a large range of progymnosperms, including the Aneurophytales. Their primary body comprises a pith that is entirely parenchymatous with xylem strands that lie in contact with the secondary xylem, two characters shared with the eustelic progymnosperm taxa Archaeopteris and Protopitys. A large number of traits remain unknown for specimens KLA 17 and KLC 25 and an assessment of their systematic position is highly doubtful. But the characters cited above suggest that they may represent a more basal grade of lignophytic trees than Pitus, Cauloxylon, Bilignea or even any of the 3 species included in the genus Eristophyton.

The three specimens from Kahlleite have distinctively small tracheids compared to those of all taxa recorded thus far in the Mississippian for which this information has been provided. Whether this character is artefactual and linked to taphonomic conditions in this area of Thuringia, was environmentally induced, or have a systematic significance will be tested in forthcoming studies of lignophytes from similarly aged sediments in the Montagne Noire region of France. Vascular traces in at least two specimens terminate within the secondary xylem, indicating that these woody plants shed their leaves while the absence of growth rings suggests that it was not linked to seasonal conditions.

Most records of Protopitys come from Visean, possibly, Namurian deposits of Western Europe (Galtier et al., 1998; Goeppert, 1852; Smith, 1962; Walton, 1969) but two specimens also have been reported from the late Tournaisian of Scotland (Galtier and Scott, 1990). The great longevity of the genus is confirmed by its new occurrence at Kahlleite, which extends its stratigraphical range to the middle Tournaisian. The same conclusion is 
drawn for Eristophyton-type axes, which, until the present work, were also reported from localities ranging from late Tournaisian to late Visean, and possibly Namurian. Eristophyton however, has a wider geographical distribution than Protopitys, which includes the northern edge of Gondwana (Chalot-Prat and Galtier, 1989).

Up to now, three genera of arborescent lignophytes have been reported from earliest deposits of Mississippian age and include Archaeopitys, Aporoxylon, and Archaeopteris. The new findings from Kahlleite demonstrate the occurrence of two additional types of putative trees during this period, represented by Protopitys and Eristophyton. These are now the earliest known occurrences of these Early Carboniferous lignophytic genera together with an indication of their diversity. We have shown that several taxa of large woody plants existed at the same time as the latest known archaeopterids, but unlike them and possibly at their expense, survived well above the D/C boundary. The idea of a landscape devoid of lignophytic trees but consisting of r-selected shrubby pteridosperms succeeding the Archaeopteris dominated forests of the Late Devonian is probably erroneous (DiMichele and Hook, 1992). The systematic turn-over documented around the $\mathrm{D} / \mathrm{C}$ boundary may not have resulted in drastic changes within the plant community structure established at the end of the Devonian.

\section{Acknowledgements}

We are grateful to Dieter Weyer for informative discussions concerning the geology and stratigraphy of the Kahlleite locality and to Konrad Bartzsch for his assistance in the field. We thank Jean Dejax and Dario De Franceschi (Museum National d'Histoire Naturelle de Paris) for the loan of Aporoxylon.

\section{References}

Beck, C. B., 1962. Plants of the New Albany Shale. II. Callixylon arnoldii sp. nov. Brittonia $14,322-327$

Beck, C. B., Wight, D. C., 1988. Progymnosperms in Origin and evolution of gymnosperms. Beck, C.B. Columbia University Press. New York. 
Chalot-Prat, F., Galtier, J., 1989. Découverte d'un tronc de gymnosperme dans une coulée du complexe volcanique carbonifère du Tazekka (Maroc oriental) et sa signification paléoécologique. C. R. Acad. Sci. Paris 309, Série II, 1735-1741.

Crane, P., 1985. Phylogenetic analysis of seed plants and the origin of Angiosperms. Ann. Mo. Bot. Gard. 72, 716-796.

Cribbs, J. E., 1939. Cauloxylon ambiguum, gen. et sp. nov., a new fossil plant from the Reed Springs Formation of southwestern Missouri. Am. J. Bot. 26, 440-449.

DiMichele, W. A., Hook, R. W., 1992. Paleozoic terrestrial ecosystems in Terrestrial ecosystems through time. Behrensmeyer, A.K., et al. Eds. The University of Chicago Press. Chicago.

Doyle, J. A., Donoghue, M. J., 1986. Seed Plant Phylogeny and the Origin of Angiosperms: An Experimental Cladistic Approach. Bot. Rev. 52 (4), 321-431.

Fairon-Demaret, M., 1986. Some uppermost Devonian megafloras: a statigraphical review. Ann. Soc. Géol. Belgique 109, 43-48.

Galtier, J., 1992. On the earliest arborescent gymnosperms. Cour. Forsch.-Inst. Senckenberg $147,119-125$.

Galtier, J., Meyer-Berthaud, B., submitted. The diversification of early arborescent seed ferns. J. Torrey Bot. Soc.

Galtier, J., Scott, A. C., 1990. On Eristophyton and other gymnosperms from the Lower Carboniferous of Castelton Bay, East Lothian, Scotland. Geobios 23, 5-19.

Galtier, J., Scott, A. C., 1994. Arborescent gymnosperms from the Visean of East Kirkton, West Lothian, Scotland. Trans. R. Soc. Edinburgh: Earth Sciences 84, 261-266.

Galtier, J., Schneider, J.-L., Grauvogel-Stamm, L., 1998. Arborescent gymnosperms and the occurence of Protopitys from the Lower Carboniferous of the Vosges, France. Rev. Paleobot. Palyno. 99, 203-215.

Galtier, J., Brown, R. E., Scott, A. C., Rex, G. M., Rowe, N. P., 1993. A late Dinantian flora from Weaklaw, East Lothian, Scotland. Spec. Pap. Paleontol. 49, 57-74.

Goeppert, H. R., 1850. Monographie der fossilen Coniferen. Nat. Verh. Holl. Maatsch. Wet. Haarlem 2, 229-230.

30 Goeppert, H. R., 1852. Fossile Flora des Uebergangsgebirges. Nova Acta Leop. Carol. 22, 252-253.

Goeppert, H. R., Stenzel, G., 1888. Nachträge zur kenntniss der Coniferenhölzer der palaezoischen Formationnen. Abh. K. Akad. Wiss. Berlin 2, 25-27. 
Gordon, W. T., 1935. The genus Pitys, Witham, emend. Trans. R. Soc. Edinburgh LVIII, 279311.

Hammond, S. E., 2004. Progymnosperms and the origin of the seed. Ph.D. thesis. Cardiff University.

5 Hörich, O., 1915. Einige strukturbietende Pflanzenreste aus deutschen Kulm und Devon. Jahrbuch der Königl. Preufs. Geologischen Landesansalt XXXVI (I 3), 520-521.

Hoskins, J. H., Cross, A. T., 1951. The structure and classification of four plants from the New Albany Shale. Am. Midl. Nat. 6, 684-716.

Hoskins, J. H., Cross, A. T., 1952. The petrification flora of the Devonian-Mississipian black shales. The Paleobotanist 1 (Birbal Sahni Memorial Volume), 215-238.

Lacey, W. S., 1953. Scottish Lower Carboniferous Plants: Eristophyton waltonii sp. nov. and Endoxylon zonatum (Kidston) Scott from Dumbartonshire. Ann. Bot. 68, 579-596.

Long, A. G., 1987. Observations on Eristophyton Zalesski, Lyginorachis waltonii Calder, and Cladoxylon edromense sp. nov. from the Lower Carboniferous Cementstone group of Scotland. Trans. R. Soc. Edinburgh 78, 73-84.

Matten L.C., 1972. Callixylon from the Maury formation (Lower Mississipian) of Tennessee 46, 711-713.

Meyer-Berthaud, B., Rowe, N. P., 1996. New mid-Tournaisian plant assemblages from Germany. 5th International Organization of Palaeobotany Conference, Santa Barbara (California). Abstract:70.

Rowe, N. P., Speck, T., Galtier, J., 1993 Biomechanical analysis of a Palaeozoic gymnosperm stem. Proc. R. Soc. London B 252, 19-28.

Scott, A. C., Galtier, J., Clayton, G., 1984. Distribution of anatomically preserved floras in the Lower Carboniferous of Western Europe. Trans. R. Soc. Edinburgh: Earth Sciences 75, 311-340.

Scott, D. H., 1902. Primary structure of certain paleozoic stems with Dadoxylon type of wood. Trans. R. Soc. Edinburgh: Earth Sciences 40 (part II, 17), 346-357.

Scott, D. H., 1923. Studies in fossil botany. 2. A. and C. Black, Ltd., London.

Scott, D. H., 1924. Fossil plants of the Calamopitys type, from the Carboniferous rocks of Scotland. Trans. R. Soc. Edinburgh 53 part III, 574-579.

Scott, D. H., Jeffrey, E. C., 1914. On fossil plants, showing structure, from the base of the Waverley Shale of Kentucky. Phil. Trans. R. Soc. B 205, 345-354.

Smith, D. L., 1962. Three fructifications from the Scottish Lower Carboniferous. Palaeontology 5, 225-237. 
Solms-Laubach, H., 1893. Ueber die in den Kalksteinen des Kulm von Glatzsich-Falkenberg in Schlesien erhaltenen structur bieten den pflanzenreste. Bot. Zei. Jahrg. 51, 197.

Speck, T., Rowe, N. P., 1994. Biomechanical analysis of Pitus dayi: early seed plant vegetative morphology and its implications on growth habit. J. Plant Res. 107, 443-460.

5 Speck, T., Rowe, N. P., 2003. Modelling primary and secondary growth processes in plants: a summary of the methodology and new data from an early lignophyte. Phil. Trans. R. Soc. London B 358, 1473-1485.

Unger, F., 1856. Beitrag zur Paläontologie des Thuringer Waldes II. Schiefer und Sandsteinflora. K. Akad. Wiss. Wien Denkschr. 11, 181-182.

Walton, J., 1957. On Protopitys with a description of a fertile specimen "Protopitys scotica" sp. nov. from the Calciferous sandstone series of Dunbartonshire. Trans. R. Soc. Edinburgh 63, 333-340.

Walton, J., 1969. On the structure of a silicified stem of Protopitys and roots associated with it from the Carboniferous Limestone, Lower Carboniferous (Mississipian) of Yorkshire, England. Am. J. Bot. 56 (7), 808-813.

Weyer, D., 1990. Field excursions to Thuringia (Germany). Guidebook. IUGS working group of the Devonian-Carboniferous boundary. pp 14-17. 


\section{Table legends}

Table 1.

5 Comparison of some significant parameters in KLC 11 and comparable size specimens of Protopitys scotica (Walton, 1957; Galtier \& Scott, 1990), Protopitys buchiana (Goeppert, 1850; Galtier et al., 1998) and Endoxylon zonatum (Scott, 1924; Lacey, 1953).

Underlined data correspond to the most common traits. Terms 'broad' and 'compact' for characterizing leaf traces as used by Walton, 1957.

10

\section{Table 2.}

Comparison of some significant parameters in KLA 17, KLC 25, Eristophyton waltonii (*Lacey, 1953, leaf trace size including secondary xylem; **Galtier \& Scott, 1990), Eristophyton fasciculare (Scott, 1902), Eristophyton beinertianum (Scott, 1902) and

15 Aporoxylon primigenium (Unger, 1856; Goeppert \& Stenzel, 1888 and new observations). 


\section{Figure legends}

Fig. 1. Geographical and stratigraphical occurrences of the Kahlleite plant deposit. (A) location map of Thuringia in Germany; (B) geological map of the Saalfeld area; (C)

5 stratigraphic position of the plant unit and other plant-bearing sequences.

Fig. 2. Camera lucida drawings of the 3 specimens from Kahlleite in transverse section. Areas in grey represent the preserved portions of eusteles; dotted lines outline the main cracks. (A) KLC 11; (B) KLA17; (C) KLC 25.

10

Fig. 3. Histogram of the size of rays in specimen KLC 11.

Fig. 4. Emission of vascular traces from the two opposite zones of primary xylem in KLC 11. Each point represents the most proximal observation of a departing trace.

15

Fig. 5. Histogram of the size of rays in specimen KLC 25. 


\section{Plate Legends}

Plate I.

5 KLC 11- Protopitys sp.

1. Oval stele, transverse section, KLC11-4, x20.

2. Secondary xylem with growth-ring, transverse section, KLC11-4, x50.

3. Elongated parenchymatous pith cells, longitudinal section, KLC11-I, x100.

4. Primary xylem at one end of the oval stele, transverse section, KLC11-4, x100.

10 5. Tangentially elongated group of metaxylem tracheids at pith-wood junction, transverse section, KLC11-4, x100.

6. Arc-shaped vascular trace with an extended band of parenchyma on adaxial side, transverse section, KLC11-3, x20.

7. Two primary xylem strands at one extremity of the stele after trace departure, transverse section, KLC11-12, x50.

8. Detail of one, possibly endarch, strand of (7), transverse section, KLC11-12, x100.

9. Branch trace, transverse section, KLC11-33, x20.

10. Secondary xylem with short uniseriate rays, tangential section, KLC11-II, x200.

11. Metaxylem tracheid wall ornementation, radial section, KLC11-I, x400.

20 12. Secondary xylem tracheids showing crowded biseriate pits (left), transversely elongated uniseriate pits (middle) and circular uniseriate pits (right), radial section, KLC11-V, x400. 13. Secondary xylem tracheid with uniseriate pitting of radial walls; cross-field pits numerous and crowded, radial section, KLC11-V. X2: secondary xylem, R: ray, x400.

Plate II

1-8. KLA17 - Eristophyton sp.

1. Circular stele, transverse section; arrows indicate position of leaf trace departure. KLA17$3011, \mathrm{x} 40$.

2. External part of stele and inner part of secondary xylem, transverse section, KLA17-17, $\mathrm{x} 50$. 
3. Detail of small mesarch strand of primary xylem lying against the secondary xylem, transverse section, KLA17-6, x100.

4. Short parenchymatous pith cells, radial section, KLA17-II, x200.

5. Uniseriate rays of secondary xylem, tangential section, KLA17-V, x100.

5 6. Multiseriate wall ornamentation of metaxylem tracheids, radial section, K1A17-II, x100.

7. Multiseriate bordered pits on the radial walls of secondary xylem tracheids, radial section, K1A17-IV, x200.

8. Leaf trace departing from stele, transverse section, KLA17-6, x50.

10

9-15. KLC 25 - Aporoxylon primigenium.

9. Small compressed stele, transverse section, KLC25-2, $\mathrm{x} 40$.

10. Mesarch primary xylem strand lying against the secondary xylem, transverse section, KLC25-2, x100.

15 11. Pith comprised of parenchymatous cells with a wide range of diameters, transverse section, KLC25-2, x100.

12. Secondary xylem, transverse section, KLC25-2, x100.

13. Long ray uniseriate in lower part, biseriate above, tangential section, KLA17-a2, x100.

14. Biseriate, partly triseriate, rays consisting of cells with different sizes and shapes, 20 tangential section, KLA17-a2, x200.

15. Leaf trace within the secondary xylem, transverse section, KLC25-2, $\mathrm{x} 40$.

Plate III

Aporoxylon primigenium Unger (specimen 19, Muséum d'Histoire Naturelle de Paris)

1. Secondary xylem, transverse section, slide $430, \mathrm{x} 100$

2. Pits on radial wall of a secondary xylem tracheid, slide $433, \mathrm{x} 100$

3. Tangential section showing rays size, slide 432 , x 100

4-6 Detail of rays, slide 432, x200 
Table 1

\begin{tabular}{|c|c|c|c|c|}
\hline & KLC11 & Protopitys scotica & Protopitys buchiana & Endoxylon zonatum \\
\hline Age \& locality & $\begin{array}{l}\text { Middle Tournaisian } \\
\text { Thuringia }\end{array}$ & $\begin{array}{l}\text { Late Tournaisian-Early } \\
\text { Visean, Scotland }\end{array}$ & $\begin{array}{l}\text { Late Visean- } \\
\text { Namurian? } \\
\text { Silesia \& Vosges }\end{array}$ & $\begin{array}{l}\text { Visean } \\
\text { Scotland }\end{array}$ \\
\hline Diameter (mm) & 24 & $\begin{array}{l}11 \text { (Galtier \& Scott's } \\
\text { specimen) }\end{array}$ & 35 & 20 (Lacey's specimen) \\
\hline Stele: shape \& & elliptical & elliptical & elliptical & circular \\
\hline diameter (mm) & $1.7 \times 1.9$ & $5 \times 7$ & $4 \times 10$ & 5 \\
\hline $\begin{array}{l}\text { Number of X1 } \\
\text { strands }\end{array}$ & 2 & 2 & 2 & 7 to 8 \\
\hline $\begin{array}{l}\text { X2 tracheid } \\
\text { diameter }(\mu \mathrm{m})\end{array}$ & $25(\operatorname{tang}) ; 24(\mathrm{rad})$ & 40 & 54.4 (tang); 68.5 (rad.) & $?$ \\
\hline $\begin{array}{l}\text { X2 tracheid radial } \\
\text { pitting }\end{array}$ & $1-2$ rows & 1 (inner wood) $-\underline{3}$ rows & $\underline{1-2}$ rows & $\underline{1-2}$ to 4 rows \\
\hline Radial pit shape & $\begin{array}{l}\text { circular and } \\
\text { transversely elongated, } \\
\text { spaced }\end{array}$ & $\begin{array}{l}\text { transversely elongated } \\
\text { (inner wood) to oval- } \\
\underline{\text { circular }}\end{array}$ & scalariform & $\begin{array}{l}\text { transversely elongated } \\
\text { (inner wood) to oval- } \\
\text { circular }\end{array}$ \\
\hline Ray height & $\underline{1}-5$ & $\underline{1-3}$ & $\underline{1}-16$ (exceptional) & 1-3 (Lacey's specimen) \\
\hline Ray width & $\underline{1}-2$ & $\overline{1}$ & $\underline{1}-2$, exceptionally 3 & $\underline{1}-2$ \\
\hline Traces & arc-shaped, 'compact' & arc-shaped, 'broad' & arc-shaped, 'compact' & circular \\
\hline Phyllotaxy & $\begin{array}{l}\text { distichous alternate, } \\
\text { internode } 2 \mathrm{~cm}\end{array}$ & $\begin{array}{l}\text { distichous alternate, } \\
\text { internode } 3 \mathrm{~cm}\end{array}$ & distichous alternate & unknown \\
\hline
\end{tabular}


Table 2.

\begin{tabular}{|c|c|c|c|c|c|c|}
\hline & KLA17 & KLC25 & $\begin{array}{l}\text { Eristophyton } \\
\text { waltonii }\end{array}$ & $\begin{array}{l}\text { Eristophyton } \\
\text { fasciculare }\end{array}$ & $\begin{array}{l}\text { Eristophyton } \\
\text { beinertianum }\end{array}$ & $\begin{array}{l}\text { Aporoxylon } \\
\text { primigenium }\end{array}$ \\
\hline Pith & parenchymatous & parenchymatous & $\begin{array}{l}\text { parenchymatous } \\
+ \text { sclerotic nests }\end{array}$ & parenchymatous & $\begin{array}{l}\text { parenchymatous } \\
+ \text { sclerotic nests }\end{array}$ & parenchymatous \\
\hline $\begin{array}{l}\text { Primary xylem } \\
\text { strands }\end{array}$ & $\begin{array}{l}\text { about } 30 \\
\text { endarch/mesarch } \\
80-230 \mu \mathrm{m}\end{array}$ & $\begin{array}{l}>18 \\
\text { mesarch } \\
100-250 \mu \mathrm{m}\end{array}$ & $\begin{array}{l}7-40 \\
\text { endarch/mesarch } \\
160 \mu \mathrm{m}\end{array}$ & $\begin{array}{l}8-9 \\
\text { mesarch } \\
\text { up to } 1 \mathrm{~mm}\end{array}$ & $\begin{array}{l}17 \\
\text { endarch/mesarch } \\
<750 \mu \mathrm{m}\end{array}$ & $\begin{array}{l}\text { about } 15 \text { on a } \\
\text { half transverse } \\
\text { section }\end{array}$ \\
\hline $\begin{array}{l}\text { In contact with } \\
\text { the wood? }\end{array}$ & yes & yes & no & no & yes & yes \\
\hline $\begin{array}{l}\text { Secondary } \\
\text { xylem pitting }\end{array}$ & 2-4 rows & $2-3$ rows & $1-5$ rows & Multiseriate & Mostly biseriate & $2-3$ rows \\
\hline Ray height & $1-20$ & $1-28$ & $1-50$ & $1-16$ & $1-26$ & $1-23$ \\
\hline Ray width & $1-2$ & $1-3$ & $1-7$ & $1-2$ & $1-(2)$ & $1-3$ \\
\hline $\begin{array}{l}\text { Leaf trace } \\
\text { diameter }\end{array}$ & $0.2 \mathrm{~mm}$ & $0.2 \times 0.3 \mathrm{~mm}$ & $\begin{array}{l}1 \mathrm{~mm}^{*} \\
0.15-0.25 \mathrm{~mm}^{* *}\end{array}$ & $0.8-1 \mathrm{~mm}$ & & \\
\hline
\end{tabular}



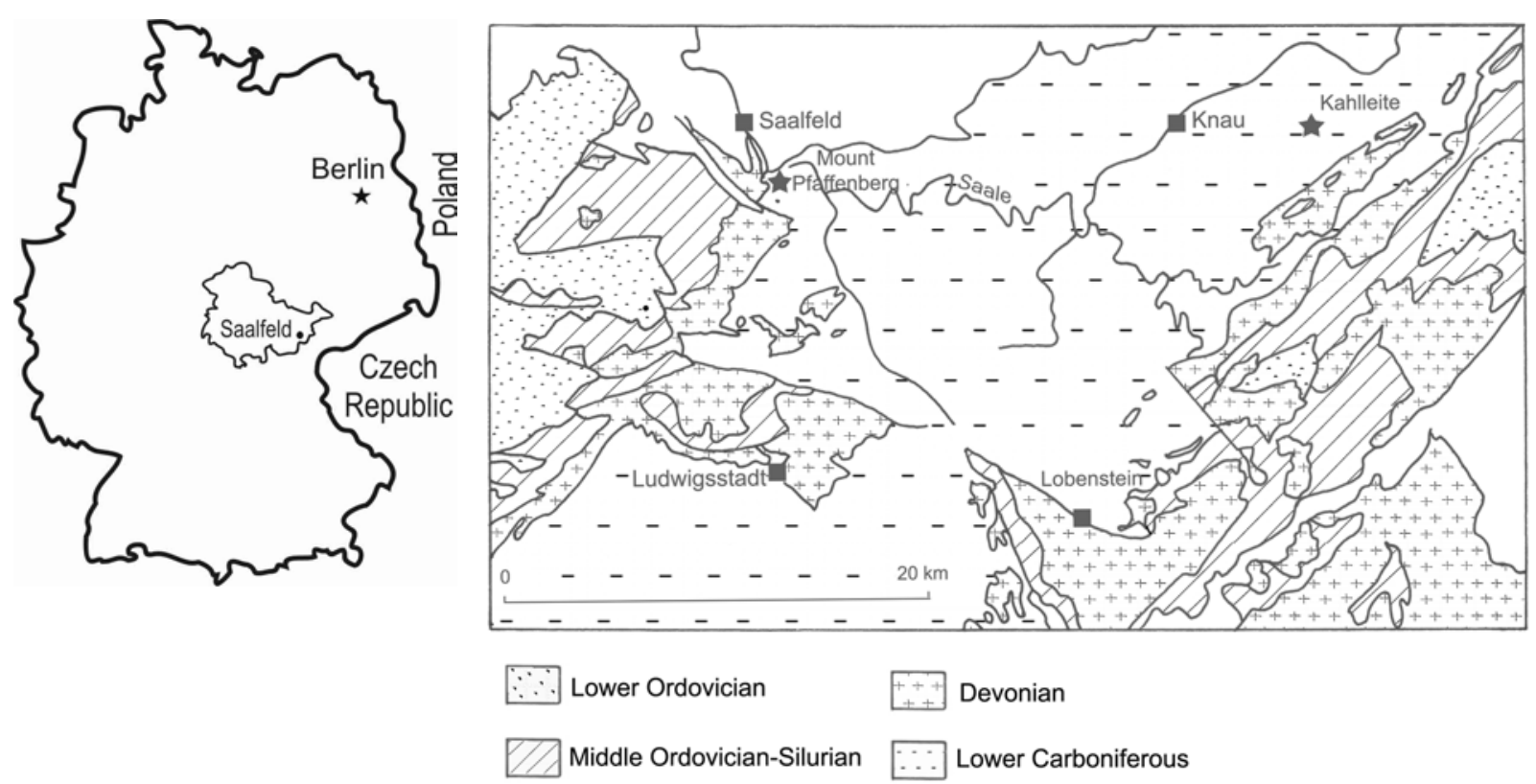

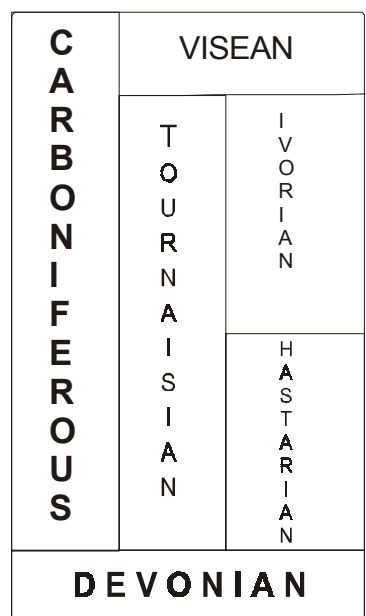
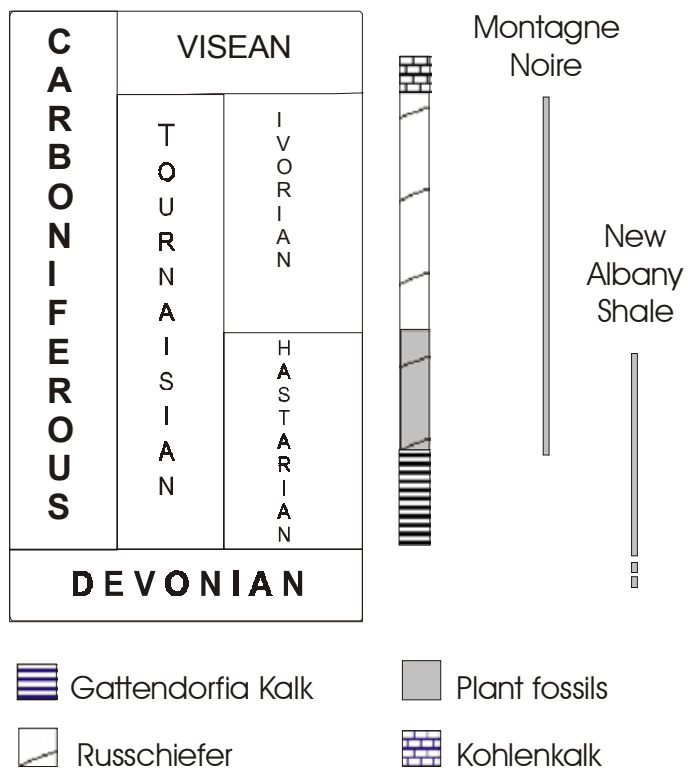

Fig. 1 
A

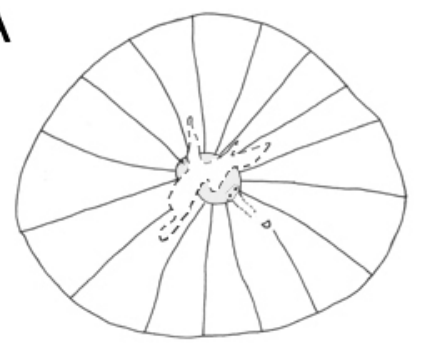

B

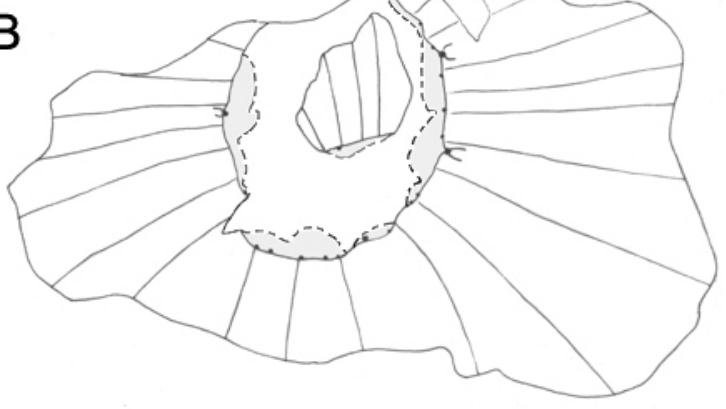

C

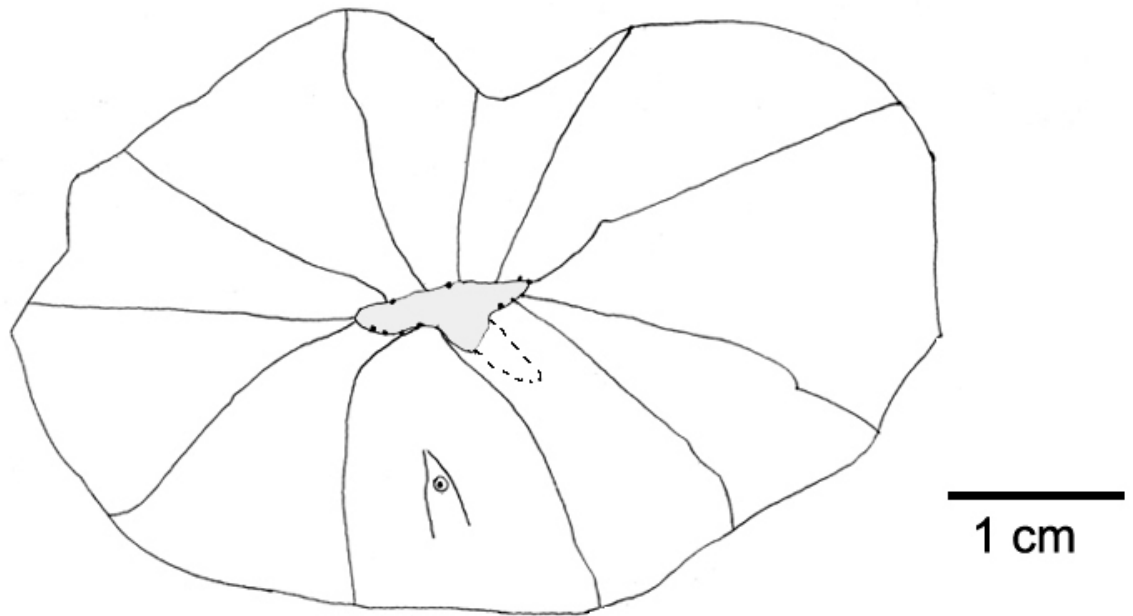

Fig. 2 


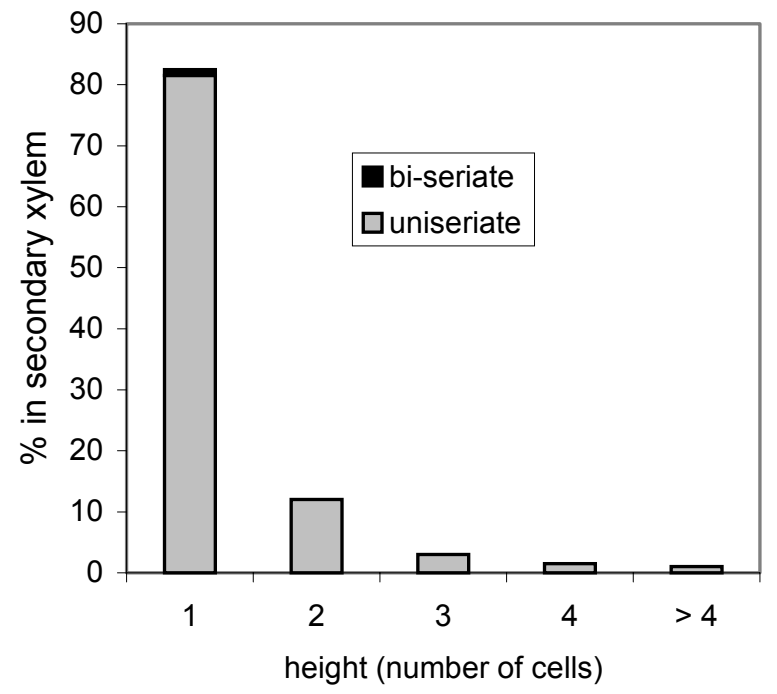

Fig. 3 


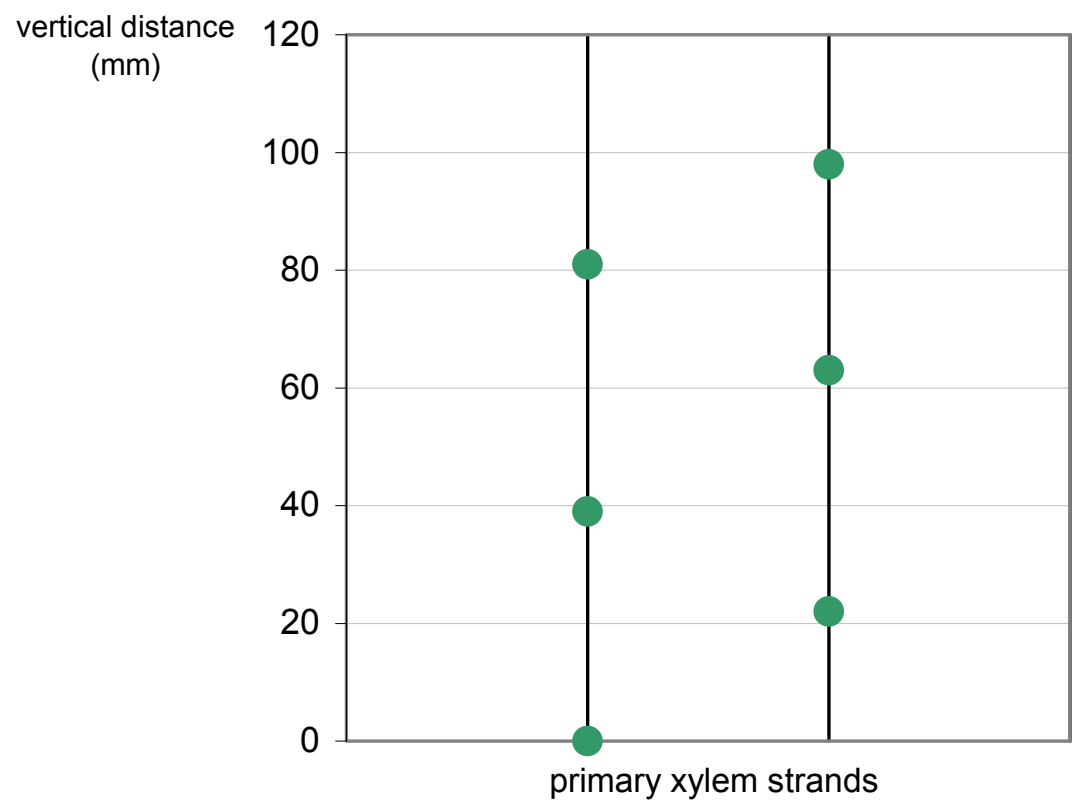

Fig. 4. 


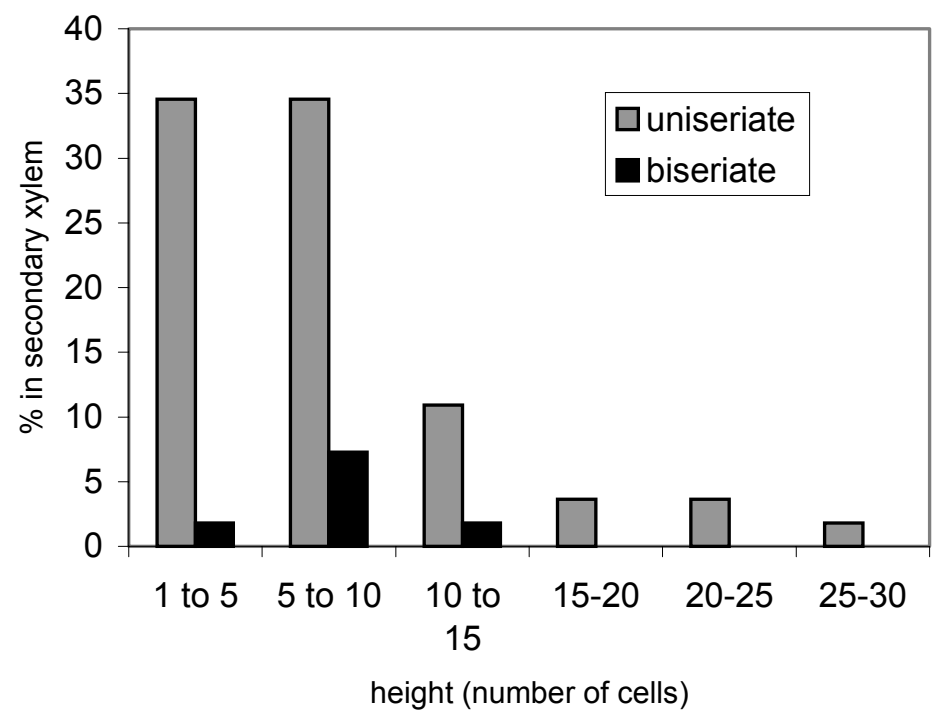

Fig. 5. 

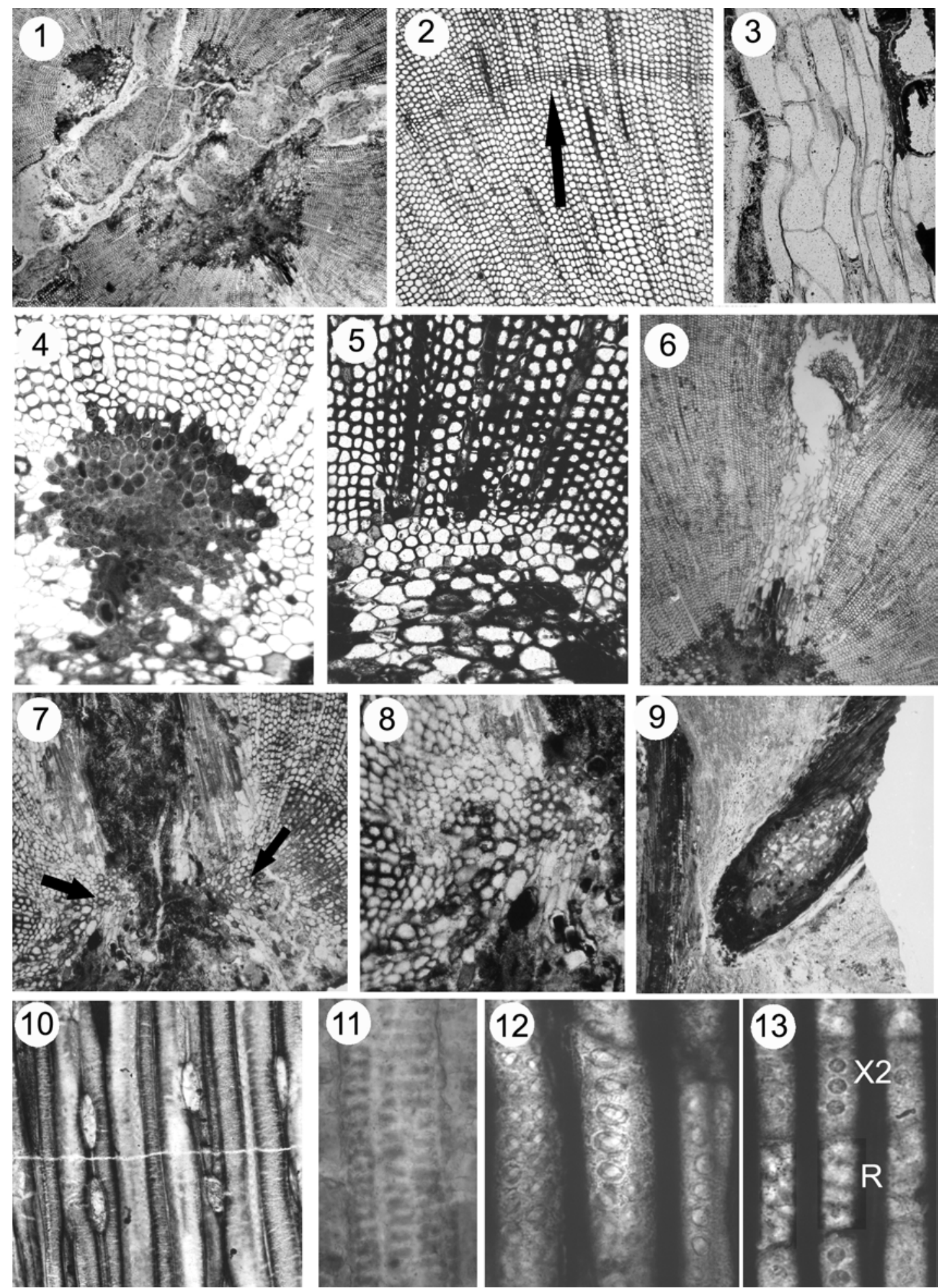

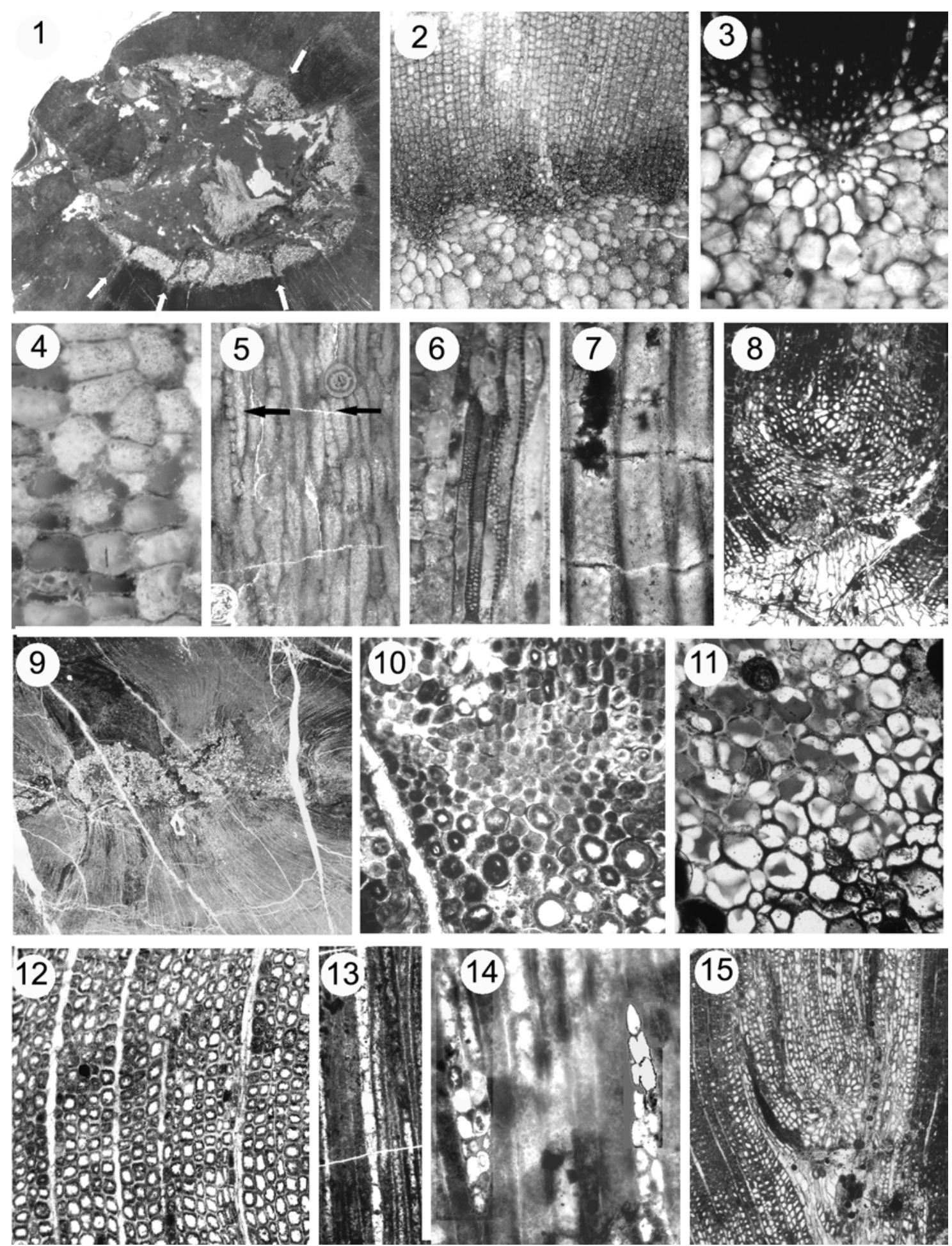

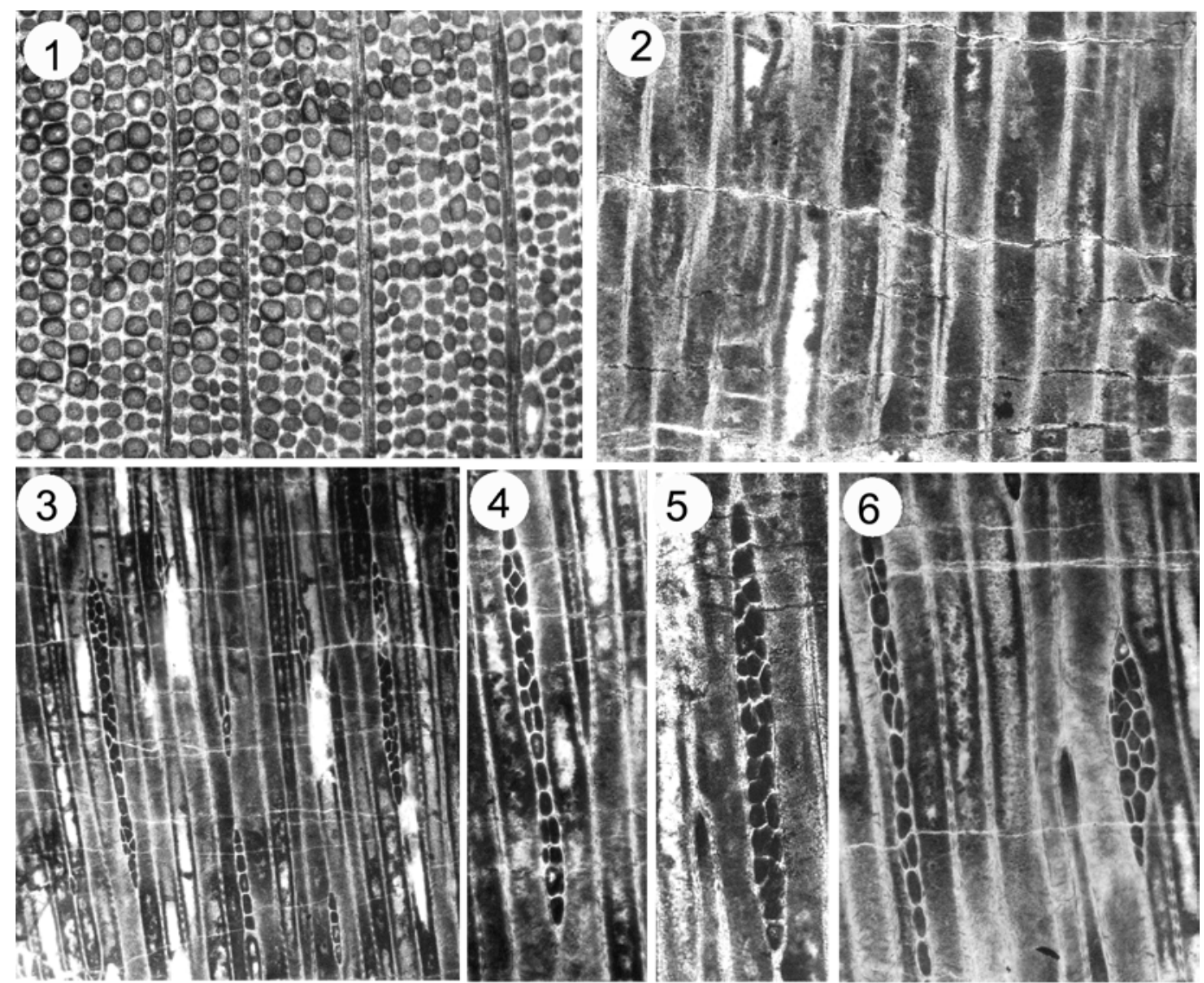